\title{
Post-antibiotic effect of azithromycin and erythromycin on streptococcal susceptibility to phagocytosis
}

\author{
M. A. RAMADAN, A. F. TAWFIK*, A. M. SHIBL and C. G. GEMMELL $\dagger$ \\ Division of Microbiology, College of Pharmacy and * College of Applied Medical Sciences, King Saud University, \\ Riyadh, Saudi Arabia and †Department of Bacteriology, Glasgow Royal Infirmary, Glasgow, Scotland
}

\begin{abstract}
Summary. The effect of azithromycin and erythromycin on growth, cell surface hydrophobicity and the susceptibility to the bactericidal activity of human polymorphonuclear leucocytes (PMNL) was examined in four Streptococcus species. Exposure to either $10 \times \mathrm{MIC}$ azithromycin or erythromycin induced a post-antibiotic effect (PAE) of between 2.4 and $4.3 \mathrm{~h}$. Erythromycin caused a longer PAE for $S$. sanguis than azithromycin under the same conditions. The cell surface charge (hydrophobic or hydrophilic) of the streptococci was altered significantly during PAE; loss of hydrophobicity was induced by both macrolides, and this effect was variable amongst the species. The decrease in hydrophobicity was not related to inhibition of growth. The effect of each drug during PAE on the interaction of opsonised suspensions of the streptococci with human PMNL revealed that erythromycin, and to a lesser extent azithromycin, increased susceptibility to the bactericidal activity of human PMNL; this effect was abolished following PAE. The present study clearly showed that PAE should not only be considered as delayed bacterial growth, but also as modulation of bacterial susceptibility to phagocytosis which may influence the outcome of the host-parasite relationship.
\end{abstract}

\section{Introduction}

The persistent suppression of bacterial growth after exposure to antimicrobial agents has been defined as the post-antibiotic effect (PAE). This may last for several hours depending on the concentration of antibiotic and the susceptibility of the target organism. ${ }^{1}$ PAE can also affect bacteria in other ways $;{ }^{2}$ some of these effects include changes in growth kinetics, ${ }^{3}$ morphology, ${ }^{4}$ inhibition of enzyme and toxin production, ${ }^{5}$ loss of adhesive properties ${ }^{6,7}$ and susceptibility to host humoral and cellular immunity. ${ }^{8}$ In other studies, these effects were usually observed when bacteria were incubated with antibiotics at levels below the MIC (sub-MIC). During PAE, bacterial physiology may also be affected by exposure to the antimicrobial agents.

Post-antibiotic leucocyte enhancement (PALE), or the effect of previous exposure to antibiotics on the susceptibility of bacteria to the phagocytic and bactericidal activities of polymorphonuclear leucocytes (PMNL), has been studied. Pruul and McDonald ${ }^{9}$ showed that several gram-negative bacteria, including Klebsiella pneumoniae and Salmonella typhimurium,

Received 7 July 1994; revised version accepted 4 Nov. 1994. became more susceptible to phagocytic killing by PMNL after exposure to supra-MIC of aztreonam. The same group of workers showed that Escherichia coli which had been exposed to chloramphenicol and quinolones became more susceptible to the bactericidal activity of phagocytes than bacteria which had not been exposed. ${ }^{10}$ Amongst the gram-positive pathogens, Staphylococcus aureus has been shown to become more susceptible to phagocytic killing after exposure to $10 \times$ MIC of penicillin, erythromycin or clindamycin. ${ }^{11}$

The present study sought to determine the consequences of PAE induced by azithromycin and erythromycin on cell surface hydrophobicity and susceptibility to the bactericidal activity of PMNL of four different species of streptococci.

\section{Materials and methods}

\section{Bacterial strains}

Streptococcus pyogenes ATCC 10389, S. mutans ATCC 10449 and S. sanguis ATCC 7864 were obtained in lyophilised form from the American Type Culture Collection. A strain of $S$. durans was isolated 
from a patient with endocarditis in King Saud University Hospital, Riyadh, Saudi Arabia.

\section{Antibiotics}

Erythromycin and azithromycin were obtained as pure reference powders with known potency from Abbott Laboratories, Chicago, USA, and Pfizer Research, Groton, USA, respectively.

\section{Determination of $M I C$}

The MIC were determined by the agar dilution method with Todd-Hewitt Agar (HI-MEDIA Laboratories, India). The agar containing antibiotic was inoculated with a standard volume $(50 \mu \mathrm{l})$ of the freshly prepared culture of the test organism $(1 \times$ $10^{4} \mathrm{cfu} / \mathrm{ml}$ ). The MIC was taken as the lowest concentration that produced inhibition of bacterial growth after overnight incubation at $37^{\circ} \mathrm{C}$.

\section{Preparation of inoculum}

All studies were performed with bacteria harvested from logarithmic phase cultures obtained by inoculating a single colony into Todd-Hewitt broth and incubating overnight at $37^{\circ} \mathrm{C}$ with shaking in a waterbath. The optical density (OD) of the resulting bacterial growth at $400 \mathrm{~nm}$ (LKB Ultrospec II, Milton Keynes) was adjusted to $0 \cdot 3$, then the culture was diluted 1 in 10 with pre-warmed fresh broth and reincubated at $37^{\circ} \mathrm{C}$ in the waterbath for $2 \mathrm{~h}$, resulting in a final cell density of $1 \times 10^{7} \mathrm{cfu} / \mathrm{ml}$. This point was defined as zero-time after exposure to antibiotic.

\section{Determination of post-antibiotic effect $(P A E)$}

The PAE was measured as described previously. ${ }^{1}$ Concentrations of antibiotic representing $10 \times$ MIC were added to the broth containing each test species at $1 \times 10^{7} \mathrm{cfu} / \mathrm{ml}$. A control broth sample without antibiotic was retained. After incubation for $1 \mathrm{~h}$ at $37^{\circ} \mathrm{C}$ in a shaking waterbath, the antibiotic content was reduced to an inactive level by diluting the cultures 1 in 1000 in pre-warmed fresh medium. The control sample was diluted in the same way and both were reincubated. Bacterial viable counts were determined by the Miles and Misra technique ${ }^{12}$ on Todd-Hewitt agar at time zero, immediately before and after drug removal and each hour thereafter for 6-8 h. The PAE was calculated from the equation PAE (hours) = $\mathrm{T}-\mathrm{C}$ where $\mathrm{T}$ is the time required for the count in $\mathrm{cfu} / \mathrm{ml}$ of the test culture to increase 10 -fold above the count observed directly after drug removal, and $\mathrm{C}$ is the time required for the count in $\mathrm{cfu} / \mathrm{ml}$ of an untreated culture to increase 10 -fold from the same time point.

\section{Measurement of cell-surface hydrophobicity}

The cell-surface hydrophobicity of untreated and antibiotic-treated cells was determined by the method of Rosenberg. ${ }^{13}$ The experiments were repeated three times to ensure reproducibility. n-Hexadecane $(0.06 \mathrm{ml})$ was added to a test-tube containing $2.4 \mathrm{ml}$ of bacterial suspension with an OD of 1.0 at $400 \mathrm{~nm}$ in phosphate buffer. The tubes were shaken for $120 \mathrm{~s}$ on a vortex mixer and then left at room temperature for $15 \mathrm{~min}$. After separation into two layers, the aqueous layer was removed and the OD was determined again at $400 \mathrm{~nm}$. The results were expressed as the percentage of OD at $400 \mathrm{~nm}$ with reference to the bacterial suspension without hexadecane.

\section{Measurement of phagocytosis}

PMNL were recovered from freshly donated heparinised venous blood and purified as described by Verhoef et al ${ }^{14}$ Final cell suspensions were adjusted to $1.2 \times 10^{6} \mathrm{PMNL} / \mathrm{ml}$ in Hanks's Balanced Salts Solution containing gelatin $0 \cdot 1 \%$ (gel-HBSS).

Normal human serum (NHS) was obtained from a pool of healthy donors and stored in 2-ml portions at $-20^{\circ} \mathrm{C}$ until required.

The susceptibility of the bacteria (pre-treated and untreated) to the bactericidal activity of human PMNL was determined by the method described by Pruul. ${ }^{2}$ The target organisms had been exposed to $10 \times$ MIC of either azithromycin or erythromycin for $1 \mathrm{~h}$. The antibiotics were removed by centrifugation and bacterial pellets were suspended in Todd-Hewitt broth and then incubated in a shaking waterbath at $37^{\circ} \mathrm{C}$. After 0,4 and $20 \mathrm{~h}$, the bacterial cells were separated by centrifugation, washed three times in phosphatebuffered saline (PBS) and adjusted turbidimetrically to a concentration of $2 \times 10^{7} \mathrm{cells} / \mathrm{ml}$. Bacteria not exposed to either macrolide were treated in an identical manner. Samples of each bacterial suspension were added to PMNL $\left(1.2 \times 10^{6}\right.$ cells $\left./ \mathrm{ml}\right)$ and NHS $10 \%$ in sterile plastic tubes, such that the ratio of bacteria: PMNL was $1: 1$. Controls without PMNL were included. All tubes were incubated at $37^{\circ} \mathrm{C}$ in a shaking waterbath. After incubation for $2 \mathrm{~h}, 20 \mu \mathrm{l}$ were added to $1 \mathrm{ml}$ of sterile distilled water and agitated for $20 \mathrm{~min}$ to disrupt the PMNL. Tests to assess the viability of bacteria after exposure to water showed no loss of bacterial viability, but $>95 \%$ of the PMNL were disrupted. Samples $(20 \mu 1)$ were spread on to ToddHewitt agar and the number of colonies was counted after overnight incubation at $37^{\circ} \mathrm{C}$. The effect of PAE on bacterial susceptibility to PMNL was determined by comparison of the percentage reduction in bacterial survival.

\section{Statistical analysis}

Results of each assay were analysed by Student's $t$ test.

\section{Results}

The measurement of PAE is presented in table I. An extended period of growth suppression was observed 
Table I. PAE of erythromycin and azithromycin on Streptococcus spp. exposed for $1 \mathrm{~h}$ to $10 \times \mathrm{MIC}$

\begin{tabular}{lll}
\hline Strain & Antibiotic & PAE (h) \\
\hline \multirow{2}{*}{ S. durans } & Erythromycin & $3 \cdot 7$ \\
& Azithromycin & $2 \cdot 4$ \\
S. mutans (ATCC 10449) & Erythromycin & $3 \cdot 8$ \\
& Azithromycin & $2 \cdot 6$ \\
S. pyogenes (ATCC 10389) & Erythromycin & $3 \cdot 8$ \\
& Azithromycin & $3 \cdot 2$ \\
S. sanguis (ATCC 7864) & Erythromycin & $4 \cdot 3$ \\
& Azithromycin & $3 \cdot 1$ \\
\hline
\end{tabular}

after exposure of each of the streptococcal strains to $10 \times$ MIC of erythromycin (average of $4 \cdot 1 \mathrm{~h}$ ). Azithromycin induced a more moderate PAE (average $2.9 \mathrm{~h}$ ) under the same conditions.

The cell-surface hydrophobicity of non-exposed streptococci and of streptococci exposed to $10 \times \mathrm{MIC}$ of either azithromycin or erythromycin is presented in table II. Generally, all the test bacteria were hydrophobic, as shown by their ability to migrate to the hexadecane layer. Bacterial hydrophobicity was decreased after exposure to antibiotic with significant differences between exposed and non-exposed cells immediately after removal of the drug (table II). At $4 \mathrm{~h}$, each of the four species exhibited decreased hydrophobicity after exposure to antibiotic. Even $20 \mathrm{~h}$ after exposure to antibiotics, there was a significant difference $(\mathrm{p}=0.02)$ between the surface charge of $S$. pyogenes exposed to erythromycin or azithromycin and untreated cells, whereas the surface charges of $S$. mutans, $S$. sanguis and $S$. durans were almost the same as the non-treated cells under the same conditions.

The effect of PAE on bacterial susceptibility to the bactericidal activity of human leucocytes is shown in table III. An increase in bacterial susceptibility to the bactericidal activity of PMNL was observed for at least $4 \mathrm{~h}$ after drug removal compared to the untreated cells (table III). Reduction in bacterial viability of all species after exposure to erythromycin was more marked during PAE; exposure to azithromycin increased the bactericidal activity of PMNL against $S$. pyogenes and $S$. durans compared to unexposed cells under the same conditions.

\section{Discussion}

The data indicate that macrolides produce a longer PAE on various Streptococcus spp. than that caused by the penicillins. This was expected, considering that inhibitors of protein synthesis induced an extended PAE on gram-positive bacteria. ${ }^{1}$ Azithromycin induced a significant PAE against $S$. pyogenes and other $\beta$-haemolytic streptococci, which is in agreement with other reports. ${ }^{15}$ It is possible that the drug concentration, the growth phase of the bacteria and the duration of exposure to the antibiotics as well as the method of removal of the drug, could be responsible for some of these differences.

During PAE, inhibitory effects were observed not only on bacterial growth but also on the characteristics of the cell surface. Thus, exposure of streptococci to macrolides was shown to have two related effects: (i) diminution of the cell-surface hydrophobicity of the treated cells; and (ii) increased killing activity by human PMNL. These drugs strongly inhibited the association of streptococci to the hydrocarbon during the PAE. S. pyogenes adheres to buccal epithelial cells by M-protein. ${ }^{16}$ The decline in the ability of the bacterial cells to associate with hexadecane, i.e., become more hydrophilic, could be explained on the

Table II. Hydrophobicity of Streptococcus spp. exposed to $10 \times \mathrm{MIC}$ of erythromycin or azithromycin for $1 \mathrm{~h}$

\begin{tabular}{|c|c|c|c|c|}
\hline \multirow[t]{2}{*}{ Strain } & \multirow{2}{*}{$\begin{array}{l}+ \text { Time } \\
\text { (h) }\end{array}$} & \multicolumn{3}{|c|}{$\begin{array}{l}\text { Percentage hydrophobicity* of cells (range) } \\
\text { exposed to }\end{array}$} \\
\hline & & No antibiotic & Erythromycin & Azithromycin \\
\hline S. durans & $\begin{array}{r}0 \\
4 \\
20\end{array}$ & $\begin{array}{l}64(61-68) \\
82(79-85) \\
86(82-91)\end{array}$ & $\begin{array}{l}\ddagger 11(9-14) \\
\ddagger 39(33-44) \\
68(62-76)\end{array}$ & $\begin{array}{r}+9(7-11) \\
+26(22-30) \\
79(70-89)\end{array}$ \\
\hline S. mutans (ATCC 10449) & $\begin{array}{r}0 \\
4 \\
20\end{array}$ & $\begin{array}{l}75(71-80) \\
92(83-98) \\
90(86-94)\end{array}$ & $\begin{array}{r}\$ 27(21-33) \\
+38(31-46) \\
85(77-94)\end{array}$ & $\begin{array}{r}\$ 36(33-38) \\
\ddagger 49(45-54) \\
92(86-97)\end{array}$ \\
\hline S. pyogenes (ATCC 10389) & $\begin{array}{r}0 \\
4 \\
20\end{array}$ & $\begin{array}{l}51(50-56) \\
64(59-70) \\
67(60-76)\end{array}$ & $\begin{array}{l}\$ 19(15-24) \\
\$ 18(15-22) \\
36(32-40)\end{array}$ & $\begin{array}{r}31(26-37) \\
+26(22-30) \\
49(45-53)\end{array}$ \\
\hline S. sanguis (ATCC 7864) & $\begin{array}{r}0 \\
4 \\
20\end{array}$ & $\begin{array}{l}62(56-68) \\
73(68-79) \\
81(71-87)\end{array}$ & $\begin{array}{r}+19(16-22) \\
38(34-43) \\
70(63-76)\end{array}$ & $\begin{array}{r}\ddagger 14(12-16) \\
\ddagger 36(33-40) \\
74(70-79)\end{array}$ \\
\hline
\end{tabular}

*Mean of three experiments. Hydrophobicity was calculated by dividing the differences between the $O D$ of the aqueous phase and that without hexadecane $(O D=1 \cdot 0)$ by 1.0 and multiplying by 100 to give the percentage hydrophobicity. 
Table III. Effect of exposure of Streptococcus spp. to $10 \times$ MIC of azithromycin or erythromycin on their susceptibility to the bactericidal activity of human PMNL

\begin{tabular}{|c|c|c|c|c|}
\hline \multirow[t]{2}{*}{ Strain } & \multirow[t]{2}{*}{ Antibiotic } & \multicolumn{3}{|c|}{$\begin{array}{l}\text { Percentage reduction of } \\
\text { number of surviving } \\
\text { bacteria (range)* at }\end{array}$} \\
\hline & & $0 \mathrm{~h} \dagger$ & $4 \mathrm{~h}$ & $20 \mathrm{~h}$ \\
\hline S. durans & $\begin{array}{l}\text { No antibiotic } \\
\text { Azithromycin } \\
\text { Erythromycin }\end{array}$ & $\begin{array}{l}37 \cdot 2 \\
(33 \cdot 1-41 \cdot 3) \\
42 \cdot 3 \\
(34 \cdot 8-49 \cdot 7) \\
\ddagger 71 \cdot 6 \\
(65 \cdot 4-76 \cdot 2)\end{array}$ & $\begin{array}{l}40 \cdot 9 \\
(35 \cdot 2-46 \cdot 4) \\
\ddagger 46 \cdot 4 \\
(41 \cdot 1-51 \cdot 4) \\
+68.8 \\
(57 \cdot 7-76.9)\end{array}$ & $\begin{array}{l}41 \cdot 3 \\
(36 \cdot 7-45 \cdot 4) \\
39 \cdot 7 \\
(34 \cdot 4-45 \cdot 2) \\
44 \cdot 7 \\
(37 \cdot 2-49 \cdot 6)\end{array}$ \\
\hline S. mutans (ATCC 10449) & $\begin{array}{l}\text { No antibiotic } \\
\text { Azithromycin } \\
\text { Erythromycin }\end{array}$ & $\begin{array}{l}56 \cdot 8 \\
(48 \cdot 1-64 \cdot 2) \\
50 \cdot 2 \\
(42 \cdot 9-59 \cdot 1) \\
+78 \cdot 5 \\
(69 \cdot 8-90 \cdot 3)\end{array}$ & $\begin{array}{c}53 \cdot 2 \\
(46 \cdot 9-60 \cdot 4) \\
53 \cdot 8 \\
(44 \cdot 9-61 \cdot 3) \\
\ddagger 74 \cdot 2 \\
(66 \cdot 2-85 \cdot 3)\end{array}$ & $\begin{array}{l}62 \cdot 6 \\
(53 \cdot 2-70 \cdot 7) \\
52 \cdot 7 \\
(47 \cdot 0-56 \cdot 4) \\
63 \cdot 4 \\
(53 \cdot 6-71 \cdot 4)\end{array}$ \\
\hline S. pyogenes (ATCC 10389) & $\begin{array}{l}\text { No antibiotic } \\
\text { Azithromycin } \\
\text { Erythromycin }\end{array}$ & $\begin{array}{l}48 \cdot 3 \\
(39.8-58 \cdot 7) \\
44.9 \\
(36.5-53.9) \\
\ddagger 69 \cdot 1 \\
(58.8-80.4)\end{array}$ & $\begin{array}{l}53.6 \\
(47.3-60.8) \\
\ddagger 50.9 \\
(45.7-57.4) \\
\ddagger 77.5 \\
(69.4-86.6)\end{array}$ & $\begin{array}{c}42 \cdot 7 \\
(39 \cdot 8-47 \cdot 5) \\
44 \cdot 6 \\
(40 \cdot 2-51 \cdot 4) \\
51 \cdot 9 \\
(44 \cdot 5-57 \cdot 3)\end{array}$ \\
\hline S. sanguis (ATCC 7864) & $\begin{array}{l}\text { No antibiotic } \\
\text { Azithromycin } \\
\text { Erythromycin }\end{array}$ & $\begin{array}{l}54 \cdot 1 \\
(45 \cdot 1-63 \cdot 2) \\
53 \cdot 0 \\
(50 \cdot 3-57 \cdot 7) \\
\ddagger 76 \cdot 6 \\
(69 \cdot 3-86 \cdot 1)\end{array}$ & $\begin{array}{l}57 \cdot 3 \\
(52.4-63.9) \\
56.4 \\
(47 \cdot 3-63.5) \\
\$ 70.5 \\
(64 \cdot 2-78.0)\end{array}$ & $\begin{array}{l}57 \cdot 0 \\
(51 \cdot 3-66 \cdot 0) \\
57 \cdot 6 \\
(51 \cdot 2-64 \cdot 3) \\
\ddagger 71 \cdot 2 \\
(62 \cdot 0-80 \cdot 4)\end{array}$ \\
\hline
\end{tabular}

*Sampling time after drug removal.

†Mean of three experiments.

$\ddagger \mathrm{p}=0.01$ by Student's $t$ test.

grounds that these drugs inhibit the synthesis of proteins, e.g., M-protein. ${ }^{17}$ During PAE, a slower bacterial growth rate may also affect adherence of $S$. sanguis, S. mitis and S. mutans. ${ }^{17,18}$

The hydrophobic nature of the cell surface of various microbial cells has been shown to influence the interaction between bacteria and PMNL and attachment of bacteria to host tissues. ${ }^{19}$ Exposure of the test streptococci to macrolides by decreasing surface hydrophobicity increased their susceptibility to killing by human PMNL. This observation has also been reported by Pruul et al. ${ }^{2}$ who found that brief exposure of streptococci to $4 \times$ MIC of erythromycin increased their susceptibility to phagocytic killing.

Several earlier studies with sub-MIC levels of various antibiotics, including lincosamindes, macrolides and penicillins, have suggested that bacterial susceptibility to killing might result from changes in the efficacy of serum opsonisation. ${ }^{2,20-22}$

PAE has been extensively studied in the hope that an understanding of this effect may justify the use of

\section{References}

1. Craig WA, Gudmundsson S. Postantibiotic effect. In: Lorian V (ed) Antibiotics in laboratory medicine, 3rd edn. Baltimore, Williams and Wilkins. 1991: 403-431.

2. Pruul $H$, Wetherall $B$, McDonald $P$. In vitro killing of erythromycin-exposed group A streptococci by polymorphonuclear leukocytes. Eur J Clin Microbiol 1986; 5: 405-410.

3. Gerber AU, Craig WA. Growth kinetics of respiratory patho-
PAE-inducing antimicrobial agents with longer dosing intervals than those currently employed without loss of efficacy. The use of antibiotics that can exploit the PAE is generally considered advantageous both in terms of cost and toxicity ${ }^{23}$ and, as this study shows, perhaps also in terms of efficacy by co-operation with the host's phagocytic cell functions.

The present study illustrates the existence of a PAE for azithromycin and erythromycin against streptococci, thereby extending the pharmacokinetic advantages of these drugs. The impact of PAE on the metabolic activity of the pathogenic bacteria is likely to be due to the residual activity of the drug within the bacterial cell. Further studies are needed to determine the clinical significance of this observation. Following PAE, bacteria may lose some of their virulence features and thus become more susceptible to host defence mechanisms.

This study was supported by a grant (CPRC 44) from the Research Center, College of Pharmacy, King Saud University, Riyadh, Saudi Arabia.

gens after short exposures to ampicillin and erythromycin in vitro. J Antimicrob Chemother 1981; 8 Suppl C: 81-91.

4. Atkinson BA, Amaral L. Sublethal concentrations of antibiotics, effects on bacteria and the immune system. $C R C$ Crit Rev Microbiol 1982; 9: 101-138.

5. Shibl AM, Gemmell CG. Effect of four antibiotics on haemolysin production and adherence to human uroepithelial cells by Escherichia coli. J Med Microbiol 1983; 16: 341-349.

6. Tylewska S, Hjertén S, Wadström T. Effect of subinhibitory 
concentrations of antibiotics on the adhesion of Streptococcus pyogenes to pharyngeal epithelial cells. Antimicrob Agents Chemother 1981; 20: 563-566.

7. Schifferli DM, Beachey EH. Bacterial adhesion: modulation by antibiotics with primary targets other than protein synthesis. Antimicrob Agents Chemother 1988; 32: 1609-1613.

8. Chopra I, Linton A. The antibacterial effects of low concentrations of antibiotics. Adv Microbial Physiol 1986; 28 : 211-259.

9. Pruul H, Lewis G, McDonald PJ. Enhanced susceptibility of gram-negative bacteria to phagocytic killing by human polymorphonuclear leukocytes after brief exposure to aztreonam. J Antimicrob Chemother 1988; 22: 675-686.

10. Pruul H, McDonald PJ. Lomefloxacin-induced modification of the kinetics of growth of gram-negative bacteria and susceptibility to phagocytic killing by human neutrophils. $J$ Antimicrob Chemother 1990; 25: 91-101.

11. McDonald PT, Wetherall BL, Pruul H. Postantibiotic leukocyte enhancement: increased susceptibility of bacteria pretreated with antibiotics to activity of leukocytes. Rev Infect Dis $1981 ; 3: 38-44$.

12. Miles AA, Misra SS, Irwin JO. The estimation of bactericida power of the blood. $J$ Hyg 1938; 38: 732-749.

13. Rosenberg M, Gutnick D, Rosenberg E. Adherence of bacteria to hydrocarbons: a simple method for measuring cellsurface hydrophobicity. FEMS Microbiol Lett 1980; 9: 29-33.

14. Verhoef J, Peterson PK, Quie PG. Kinetics of staphylococcal opsonization, attachment, ingestion and killing by human polymorphonuclear leukocytes: a quantitative assay using $\left[{ }^{3} \mathrm{H}\right]$ thymidine labeled bacteria. $J$ Immunol Methods 1977 ; 14: 303-311.
15. Debbia EA, Molinari G, Paglia P, Schito GC. Post-antibiotic effect of azithromycin on respiratory tract pathogens. Drugs Exp Clin Res 1990; 16: 615-619.

16. Smith $H$. Microbial surfaces in relation to pathogenicity. Bacteriol Rev 1977; 41: 475-500.

17. Rogers AL, Pilowsky K, Zilm PS. The effect of growth rate on the adhesion of oral bacteria Streptococcus mutans and Streptococcus milleri. Arch Oral Biol 1984; 29: 147-150.

18. Bernard J-P, Francioli P, Glauser MP. Vancomycin prophylaxis of experimental Streptococcus sanguis: inhibition of bacterial adherence rather than bacterial killing. $J$ Clin Invest $1981 ; 68$ : 1113-1116.

19. Rosenberg M, Rosenberg E, Judes H, Weiss E. Bacterial adherence to hydrocarbons and to surfaces in the oral cavity. FEMS Microbiol Lett 1983; 20 : 1-5.

20. Pascual A, Martinez-Martinez L, Aragon J, Perea EJ. Effect of amoxycillin and calvulanic acid, alone and in combination, on human polymorphonuclear leukocyte function against Staphylococcus aureus. Eur J Clin Microbiol Infect Dis $1989 ; 8: 277-281$.

21. Pascual A, Lopez-Lopez GL, Aragon J, Perea EJ. Effect of azithromycin, roxithromycin and erythromycin on human polymorphonuclear leukocyte function against Staphylococcus aureus. J Chemother 1990; 36: 422-427.

22. Gemmell CG, Peterson PK, Schmeling D et al. Potentiation of opsonization and phagocytosis of Streptococcus pyogenes following growth in the presence of clindamycin. $J$ Clin Invest $1981 ; 67$ : 1249-1256.

23. Vogelman B, Gudmundsson S, Leggett J, Turnidge J, Ebert S, Craig WA. Correlation of antimicrobial pharmacokinetic parameters with therapeutic efficacy in an animal model. $J$ Infect Dis 1988; 158: 831-847. 